\title{
Reconstruction of landscape paleohydrology using the sediment archives of three dystrophic lakes in northeastern Poland
}

\author{
Danuta Drzymulska • Magdalena Fiłoc • \\ Mirosława Kupryjanowicz
}

Received: 3 April 2012/ Accepted: 18 November 2013/Published online: 4 December 2013

(C) The Author(s) 2013. This article is published with open access at Springerlink.com

\begin{abstract}
Sediment layers of uniform age within lakes (isochrones) and their patterns reflect accumulation processes which can be correlated with hydrologic conditions in lake basins. The sedimentary archives in three small dystrophic lakes in northeastern Poland are described based on the correlation of local pollen assemblage zones in cores that were collected from the centers and margins of each lake. Past regional groundwater levels could be discerned from the shape of the isochrones, whether plane parallel or concave in configuration in relation to the lake basin shape. The concave configuration of the isochrones in the studied lakes shows that regional groundwater levels remained mostly high and stable throughout their history. The water levels in each lake during the Late Glacial and throughout the Holocene were different and no single, common water-level fluctuation pattern was identified in the three water bodies. The lack of such a finding suggests that the lakes are influenced dominantly by local hydrological factors.
\end{abstract}

Electronic supplementary material The online version of this article (doi:10.1007/s10933-013-9754-2) contains supplementary material, which is available to authorized users.

D. Drzymulska $(\bowtie) \cdot$ M. Fiłoc $\cdot$ M. Kupryjanowicz Department of Botany, Institute of Biology, University of Białystok, Świerkowa 20b, 15-950 Bialystok, Poland e-mail:drzym@uwb.edu.pl

M. Kupryjanowicz

e-mail: m.kupryjanowicz@uwb.edu.pl
Keywords Pollen assemblage zone correlation . Isochrone · Water level · Lake evolution .

Kettle hole

\section{Introduction}

The type and pattern of sediment accumulation in lakes are determined by many external and internal environmental factors (Bloesch 2004). One of the most important factors is the water level, especially in the formation of littoral peat mires. Among other things, water fluctuations, as related to the regional groundwater level, affect the spatial extent of lacustrine accumulation; this extent decreases when the water table drops, and increases when the water table rises (Björk 2010). With regional groundwater levels connected to lake levels, the sediment layers accumulate over both the profundal and littoral zones (Gaudig et al. 2006). This accumulation results in a concave pattern of isochrones, i.e. sediment layers of the same general age, that follow the shape of the basin (Fig. 1a). Conversely, if regional groundwater level is lower than the lake depressions and not directly connected to lake water level, lakes and ponds are formed only in these depressions where the bottom is sealed by clay and loam, thus precipitation and inflow from the catchment can collect. Some of these water bodies contain bottom sediments sealed off by humus colloids (self-sealing mechanism), which can include kettle holes (Timmermann 2000; Joosten and Succow 
2001; Timmermann and Succow 2001). During the initial phase of the development of kettle hole mires, the self-sealing process occurs only in the deepest part of the basin. The self-sealing progresses systematically as vegetation growth dominates the sediment accumulation. With time the lake can enlarge even if regional groundwater levels are below the lake depression because the high organic content of the mire lake sediment seals in any water input from precipitation and the watershed. The isochrone pattern in such lakes is theorized to be parallel to the lake surface (Fig. 1b).

Lacustrine and peat layers deposited during a definitive time zone, i.e. isochrones (Gaudig et al. 2006), are useful for reconstructing paleoenvironmental accumulation conditions (Digerfeldt 1986; Digerfeldt et al. 2007). The thicknesses and patterns of the isochrones provide important information about the paleohydrological conditions of any mire or lake. The absence of sediment during a certain age may indicate low water levels and no sedimentation. These patterns may give clues to past climate and associated hydrological changes (i.e. regional groundwater levels) during the life of a lake.

Data derived from the sedimentary archives in three dystrophic lakes [Lake Ślepe (L. Ślepe), Lake Suchar II (L. Suchar II), and Lake Suchar Wielki (L. Suchar Wielki)] in northeastern Poland located within the Wigry National Park (Fig. 2) are studied here to reconstruct past climate and hydrological changes in northeastern Poland. These small (average surface areas of $0.5-3 \mathrm{ha}$ ) lakes without surface flow (i.e.

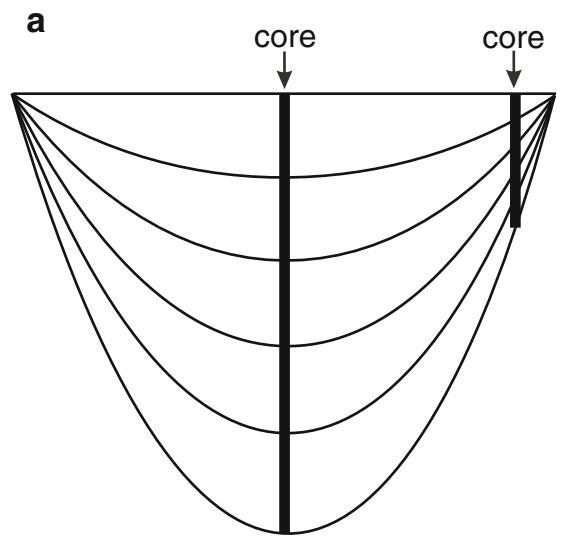

Fig. 1 Hypothetical patterns of sediment isochrones resulting from a accumulation on entire surface of lake bottom with high regional groundwater levels, and b self-sealing lake or mire rivers and streams) resemble kettle hole mires located in Bory Tucholskie (Kowalewski and Milecka 2003; Lamentowicz et al. 2007) and nearby in the Suwałki Lakeland (Żurek et al. 2006). All of these lakes have floating mats and are surrounded by coniferous forest.

However, opinions differ regarding whether the dystrophic lakes in Wigry National Park are indeed kettle hole lakes. There are many classifications of kettle holes based on very different criteria, such as the hydroperiod (Stewart and Kantrud 1971) or local hydrogeomorphic conditions (Kalettka and Rudat 2006). Deep lakes or mires and shallow basins can originate as kettle holes (Filion and Bégin 1998). Based on the geomorphological and local climatic conditions of the three lakes in Wigry National Park, it is plausible that they actually are kettle hole lakes. Similar to the known kettle hole lakes in northern Germany (Mecklenburg, Brandenburg) and northern Poland, such as Bory Tucholskie (Kowalewski and Milecka 2003; Lamentowicz et al. 2007), the Wigry park lakes are located in a young glaciated area with moraines and surrounded by forests. The presence of forested moraines affects the local climatic conditions by limiting the insolation and exchange of air masses over the lake surface (Schindler 1996) and can affect groundwater flow. However, a geomorphologic understanding of the kettle hole concept should be supported by more genetic information (Timmermann and Succow 2001). No subsurface data are yet available for these lake depressions; however, circumstantial evidence allows an assumption for kettle hole origin at the present time.

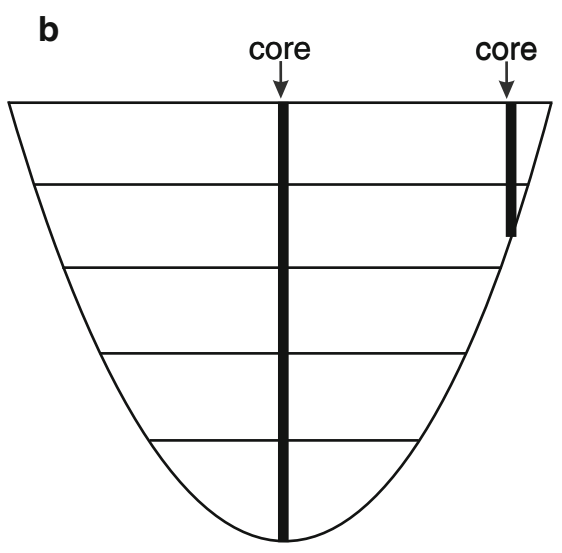

formation with lower regional groundwater levels, modified from Gaudig et al. (2006) 


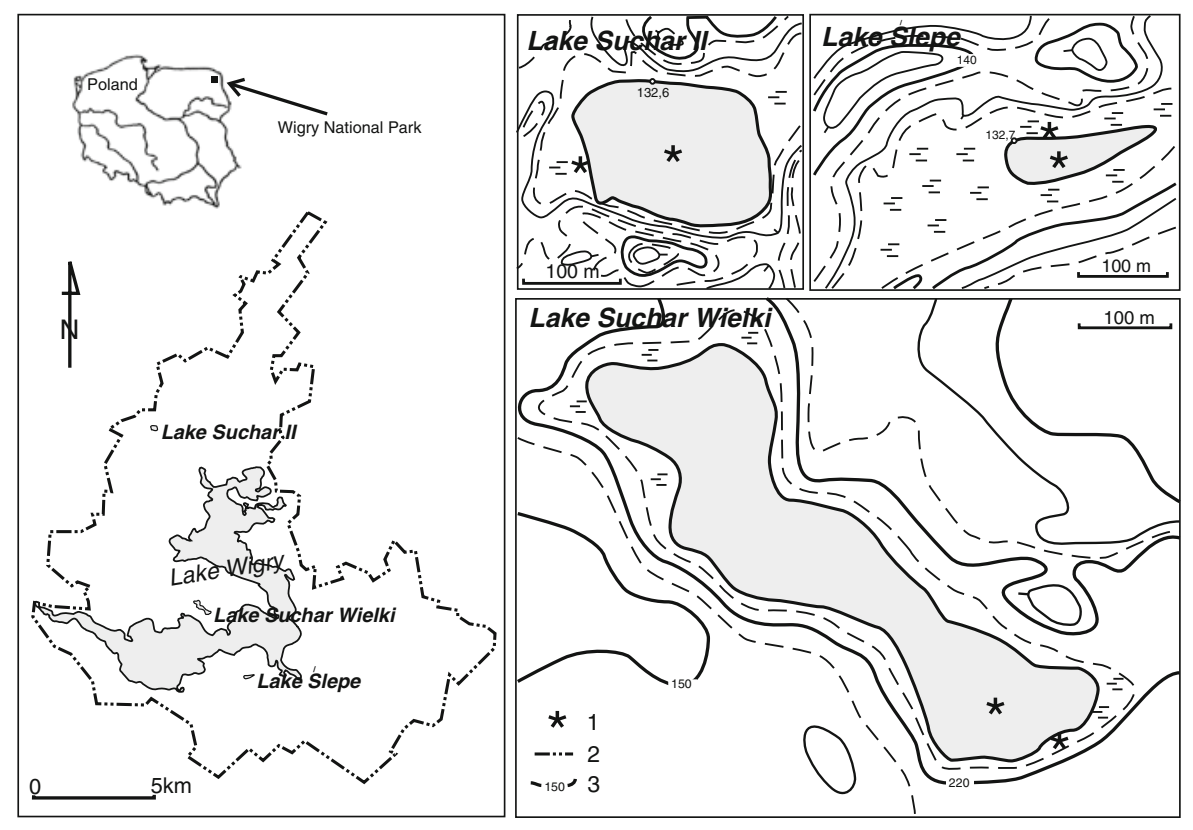

Fig. 2 Wigry National Park and the location of the three studied lakes: Ślepe, Suchar II, and Suchar Wielki. 1-location of cores, 2park border, 3 - topographic lines

The objective of this research is to document the isochrone morphology, and thus water level changes, within the three Wigry park lakes through coring to delineate the past hydrology, and thus paleoclimate. Comparisons to the water levels in other mires and lakes in northern Poland in the Late Glacial and Holocene, as compiled by Ralska-Jasiewiczowa and Starkel (1988) will aid in the determination whether water level changes are truly based on climate or local factors associated with catchment characteristics. In peat-forming environments, the isochrone method may work as a sensitive indicator for studying catchments and processes that shape the characteristics of a lake.

Study area

The three dystrophic lakes located in northeastern Poland (Fig. 2) in Wigry National Park (WNP) exist within two physical-geographical mesoregions: the East Suwałki Lakeland and the Augustów Upland; both regions are part of the Lithuanian Lakeland (Kondracki 1994). The geomorphology of this area was shaped during the Pomeranian phase of the main stadial of the Weichselian (Vistulian) glaciation (Marks 2002). A number of kames, eskers, and high frontal moraines are present in the northern and middle parts of
WNP, whereas the southern part of the park contains an extensive sandur with strongly developed primary glacial topography (Ber 2009). The climate of this area is temperate transitional between maritime and continental, with a tendency toward continentality.

The young glacial dystrophic lakes of WNP are located in the vicinity of Lake Wigry, one of the largest and deepest lakes in Poland (area $21.63 \mathrm{~km}^{2}$, max depth $74.2 \mathrm{~m}$ ). L. Ślepe (0.6 ha, $5.5 \mathrm{~m} \max$ depth, $54^{\circ} 00^{\prime} 35^{\prime \prime} \mathrm{N}, 23^{\circ} 06^{\prime} 46^{\prime \prime} \mathrm{E}$ ) is located near the southern shore of Lake Wigry. L. Suchar II (2.6 ha, $9.5 \mathrm{~m}$ max depth, $\left.54^{\circ} 05^{\prime} 14^{\prime \prime} \mathrm{N}, 23^{\circ} 01^{\prime} 03^{\prime \prime} \mathrm{E}\right)$ is located northwest of Lake Wigry, and L. Suchar Wielki (8.9 ha, $9.6 \mathrm{~m} \max$ depth, $54^{\circ} 01^{\prime} 41^{\prime \prime} \mathrm{N}$, $23^{\circ} 03^{\prime} 21^{\prime \prime} \mathrm{E}$ ) is located west of Lake Wigry (Fig. 2).

Each of the studied lakes is characterized by the zoning of vegetation. Along the sublittoral to littoral, a floating mat differentiated into two zones is present. Closer to open water, a quaking floating mat composed of Rhynchospora alba (L.) Vahl, Scheuchzeria plaustris L., Carex limosa L., Carex rostrata Stokes, and Carex lasiocarpa Ehrh. is present. Among the mosses, Sphagnum angustifolium (Russ.) C. Jens., and Sphagnum fallax $\mathrm{H}$. Klinggr. dominate. Closer to shore, a non-quaking floating mat composed of Eriophorum vaginatum L., Sphagnum magellanicum Brid., Andromeda polifolia L., Vaccinium oxycoccos L., and Drosera 
rotundifolia $\mathrm{L}$. is present. The last vegetation zone of each lake consists of marshy coniferous forest growing on a peat substratum on the margin of the lake. The forest trees include Pinus sylvestris L., Picea abies (L.) Karsten, and Betula pubescens Ehrh. In the ground cover, in addition to Ledum palustre L., other species typically found in coniferous forests and mires are identified (Vaccinium myrtillus L., V. uliginosum L., Pleurozium schreberi (Willd.) Mitten., Dicranum polysetum Sw. and mires (S. magellanicum Brid., E. vaginatum L., V. oxycoccos L.).

\section{Materials and methods}

\section{Fieldwork}

Two sediment cores were collected from each of the lakes selected for study; the first from the profundal sediments and the second from the sublittoral zone covered by floating vegetation mats. A modified version of the method described by Gaudig et al. (2006) was used; this modified method consisted of collecting one complete sublittoral core instead of samples of lacustrine sediments in a transect leading from the center of the lake towards the shore. This modification does not influence the final result to delineate the isochrone pattern, either concave-downward or planar (Fig. 1).

The cores from the marginal littoral zones were collected using a Russian corer $(50 \mathrm{~cm}$ long and $8 \mathrm{~cm}$ in diameter). The lengths of the cores were L. Ślepe$4.23 \mathrm{~m} \mathrm{~L}$. Suchar II-7.0 m, and L. Suchar Wielki$3.0 \mathrm{~m}$. Cores from the profundal zones were collected using a Więckowski probe $(120 \mathrm{~cm}$ long and $5 \mathrm{~cm}$ in diameter) while standing on the winter ice surface. The lengths of these cores were L. Ślepe- $5.4 \mathrm{~m} \mathrm{~L}$. Suchar II-6.1 m, and L. Suchar Wielki-9.06 m. The locations of all of the coring sites are presented in Fig. 2.

\section{Laboratory analyses}

\section{Lithology}

Sediment lithology of each core was documented in the laboratory. The primary vegetation remains in the samples were identified taxonomically under a light microscope, which permitted a description of the peat units. The lacustrine sediment samples were tested for carbonates by treating them with $10 \% \mathrm{HCl}$ and observing them for effervescence. The samples that effervesced were analyzed via the calcium carbonate volumetric calcimeter method using a Scheibler analyzer produced by WPL, Gliwice, Poland. Lacustrine chalk, calcareous gyttja, detritus-calcareous gyttja, fine-detritus gyttja, dy, and peat were logged in accordance with the methods recommended by Tobolski (2000). According to the classification scheme of Schnurrenberger et al. (2003), these limnic sediments belong in the biogenic sediment class in the sapropel series. Other deposits, such as gravel, sand, silt, and clay, were logged visually and under a stereoscopic microscope.

\section{Pollen analysis and pollen zone correlation}

For pollen analysis, samples $1 \mathrm{~cm}^{3}$ in size were taken from all cores at vertical intervals of $5-20 \mathrm{~cm}$. These intervals depended on the rate of sediment accumulation and variations in the resolution of the pollen record in each profile. Next, a standard chemical preparation of $10 \% \mathrm{HCl}, 10 \% \mathrm{KOH}$, and $40 \% \mathrm{HF}$ was used, and acetolysis and mounting in glycerine (Berglund and Ralska-Jasiewiczowa 1986) were performed. The samples were analyzed palynologically using a Nicon Eclipse 400 light microscope with $600 \times$ magnification. The pollen and spores were identified using keys (Beug 2004) and the reference collection of modern pollen slides at the Institute of Biology, University of Białystok. On average, 500 grains of tree and shrub pollen were determined, as well as all accompanying pollen grains of herbaceous plants and spores.

The frequencies of the dominant or otherwise important taxa were summarized as simplified pollen percentage diagrams, prepared using POLPAL software (Walanus and Nalepka 1999; Nalepka and Walanus 2003). The percentage value of each pollen taxon was calculated in relation to the total of tree, shrub (AP), and herbaceous plant pollen (NAP), excluding pollen of limnophytes and telmatophytes and the spores of Pteridophyta and Sphagnum. The frequency of the excluded taxa was counted in relation to the total sum of pollen.

The pollen percentage diagrams were divided into local pollen assemblage zones (L PAZ). The delineation of the zones was based on the taxonomic 
composition and percentage values of the primary or characteristic taxa recorded in the pollen spectra, supported by CONISS (constrained incremental sums of squares) numerical analysis (Grimm 1987). The results of this numerical analysis display a profile's division in the form of a dendrogram whose branches link samples according to appropriate measures of similarity (Walanus 1995). Next, it was determined how many break points in each dendrogram were appropriate to use as boundaries of pollen zones. In all profiles, the number of break points was delineated subjectively, accepting all those designated by CONISS boundaries of higher rank to the third cut of the dendrogram inclusively. In addition, in one position in the marginal profile from Lake Suchar II (Fig. 4), a boundary designated by CONISS as a boundary of lower rank was included. Due to this inclusion, a pollen zone with only one pollen spectrum (SII-C; Fig. 4) was delineated. Even a single sample with a specific pollen spectrum should be identified as a pollen zone, particularly if this sample may be correlated with a pollen zone in another part of the same lake.

To identify a pattern of isochrones, the local pollen assemblage zones from the marginal and central parts of each lake were correlated. A sample similarity matrix (SSM) analysis was performed to identify the most similar pollen spectra in a set of two correlated profiles (Nalepka and Walanus 2003). The stratigraphical sequence of samples from the first profile was plotted vertically, and the second sequence was plotted horizontally. A graphical representation of the similarity between given samples was plotted as a black square with an area proportional to the degree of similarity. The correlation of pollen zones from the marginal and central cores of each lake was difficult because of the high amounts of local pollen in the cores from the littoral margin (e.g., very high values of Picea abies and Pinus sylvestris t. in the upper part of the marginal profile from L. Suchar II) and numerous interruptions (hiatuses). The SSM indicated the clear possibility of such a correlation only in some parts of the correlated profiles. In the remaining areas, it was necessary to complete the numerical analyses by subjective identification of corresponding pollen zones, which was performed after correcting for differences between the local and regional pollen records.

Absolute age of sediments

Selected samples of sediments were dated using AMS (Accelerator Mass Spectrometry) in the Poznań Radiocarbon Laboratory (Poz) or in the Gliwice Radiocarbon Laboratory (GdA). The online software OxCal 4.1 (Bronk Ramsey 2009) was used to calibrate the radiocarbon ages of the samples. The radiocarbon dates are presented in detail in Table 1.

To improve the age assessment of the profiles, the sample ages were also determined indirectly by correlating the pollen spectra from the central parts of the analyzed lakes with the radiometrically welldated profile from nearby Lake Wigry (Kupryjanowicz 2007). Pollen diagrams from one region and from the same period are similar in terms of basic features, permitting their correlation. When one diagram allowed assignment of absolute age dates, its timescale was then applied to a neighboring profile (Ralska-Jasiewiczowa et al. 2004). Correlation of profiles was performed using the program MultCor (Walanus and Nalepka 2006). This numerical method was based on comparisons of the percentages of selected pollen taxa in a sample; the taxa most important in terms of ecological interpretation were those of the primary trees and shrubs (Pinus sylvestris t., Betula alba t., Corylus avellana, Ulmus, Tilia cordata, Fraxinux excelsior, Picea abies t., Fagus sylvatica) and of certain herbs (Artemisia, Chenopodiaceae, Poaceae, Cerealia t., Secale cereale).

Table 1 AMS radiocarbon ages and calibrated ages for material from studied profiles

\begin{tabular}{|c|c|c|c|c|c|}
\hline Core & Depth $(\mathrm{cm})$ & Material & AMS laboratory number & ${ }^{14} \mathrm{C}$ age $(\mathrm{BP})$ & $\begin{array}{l}\text { Calibrated age } \\
\text { (cal year BP) } \\
95.4 \% \text { probability }\end{array}$ \\
\hline $\mathrm{LS}$-foreshore & 420 & Stems of brown mosses & Poz-30006 & $9,560 \pm 35$ & $11,042-10,796$ \\
\hline LSII_lake basin & 1,217 & Plant remains & GdA-2372 & $10,120 \pm 30$ & $11,975-11,505$ \\
\hline LSII—foreshore & 295 & Stems of peat mosses & GdA-2375 & $3,080 \pm 20$ & $3,365-3,245$ \\
\hline LSW-foreshore & 263 & Stems of peat mosses & Poz-38254 & $6,260 \pm 40$ & $7,243-7,165$ \\
\hline
\end{tabular}




\section{Results}

Local pollen assemblage zones and their chronostratigraphical correlation

\section{Lake Ślepe}

The pollen diagram from the profundal zone of L. Ślepe was subdivided into nine pollen assemblage zones (LS-1 to LS-9 L PAZ), and the diagram from the littoral area was subdivided into six zones (LS-A to LS-F L PAZ) (Fig. 3; Table 2). The SSM indicated a possible correlation between pollen zone LS-1, from the center of the lake, and zones LS-A and LS-B, from the marginal parts of the lake, between zones LS-2 and LS-C, and between zones LS-3 and LS-D (ESM 1).

Fig. 3 Lake Ślepe.

Simplified pollen percentage diagrams from (selected pollen curves only): a littoral zone, b profundal zone
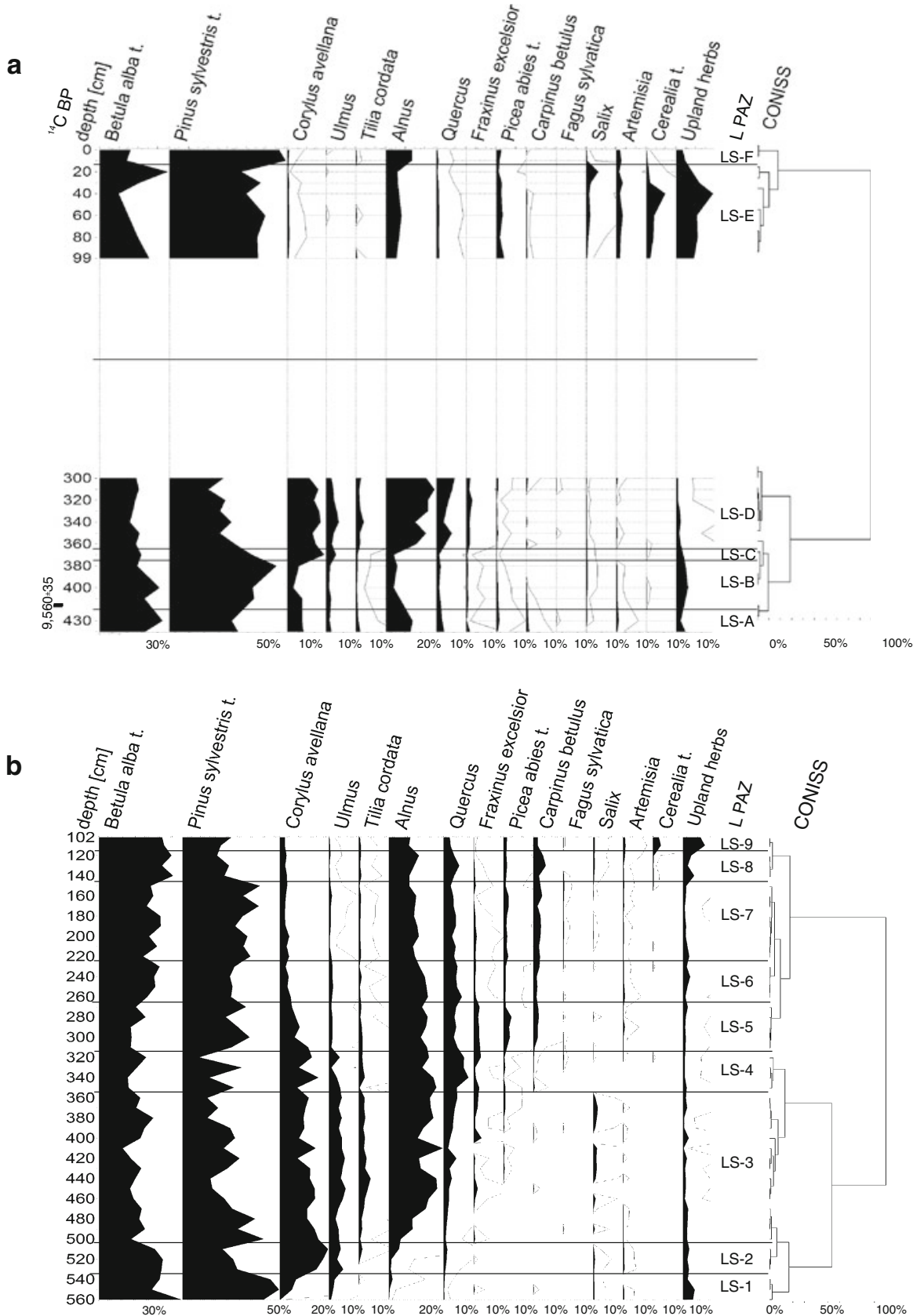


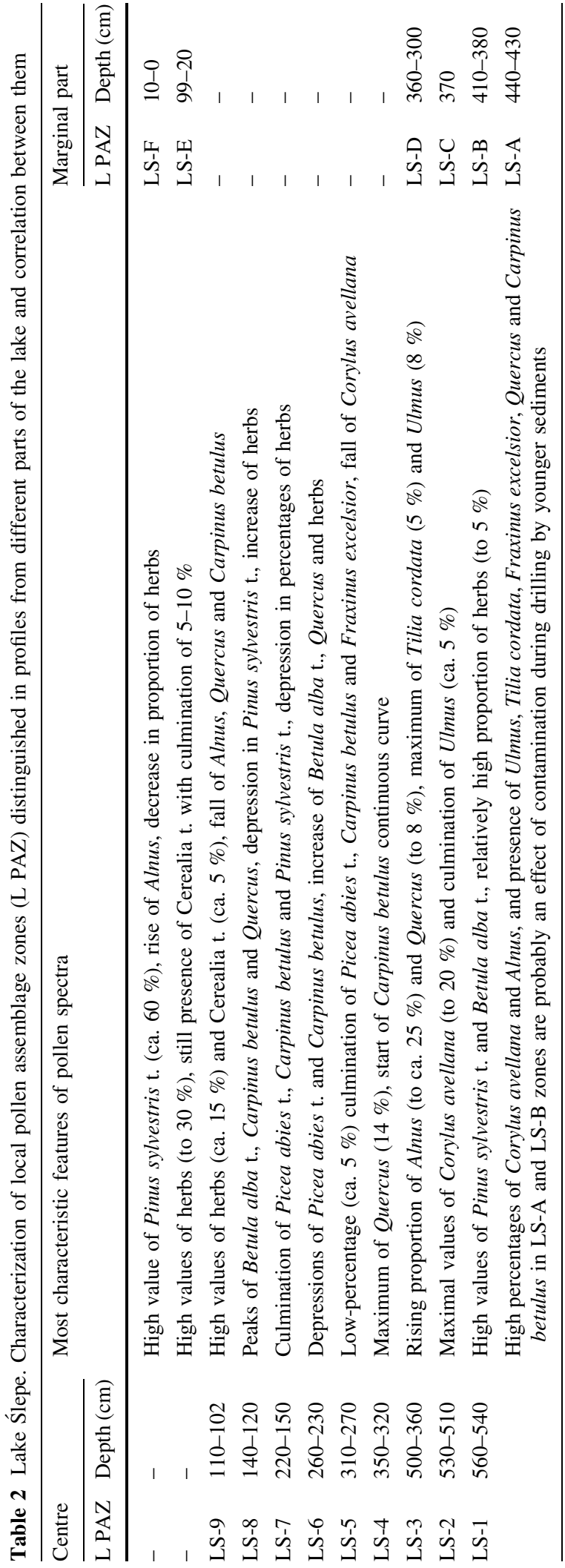

Lake Suchar II

The pollen diagram from the profundal zone of L. Suchar II was subdivided into ten pollen zones (from LSII-1 to LSII-10 L PAZ), and the pollen diagram from the littoral area was subdivided into eleven zones (from LSII-A to LSII-K) (Fig. 4; Table 3). The SSM indicated four unequivocal correlations between pollen zones in the central and marginal parts of the lake: LSII-1, LSII-2 and LSII-C, LSII-3 and LSII-D, LSII-4 and LSII-E, and LSII-7 and LSII-F (ESM 2). The correlations between remaining zones were based on a subjective evaluation of similarities (Table 3).

\section{Lake Suchar Wielki}

The pollen diagram from the profundal zone of L. Suchar Wielki was subdivided into nine pollen assemblage zones (from LSW-1 to LSW-9), and the diagram from the littoral area was subdivided into seven zones (from LSW-A to LSW-G) (Fig. 5; Table 4). The SSM indicated three unequivocal correlations between pollen zones in the central and marginal parts of the lake: LSW-1 and LSW-A, LSW-6 and LSW-B, and LSW-7 and LSW-C, LSW-D, LSW-E (ESM 3). The correlations between the two remaining zones were made after a subjective evaluation of similarities (Table 4).

Isochrones and age

Based on the chronostratigraphical correlation of the profiles from the central and marginal areas of the lakes, delineation of isochrones was possible (Figs. 3, 4, 5). Three, six, and five isochrones were identified in L. Ślepe, L. Suchar II and L. Suchar Wielki, respectively. The program MultCor was used to identify the pollen spectra in the profile from Lake Wigry most similar to those from the central parts of the studied lakes and to connect these spectra (ESM 4). The age of the regional pollen zones of the Lake Wigry profile was transferred to the local pollen zones of the three studied cores (Fig. 6). This age assessment corresponds with the results of radiocarbon dating presented in Table 1. All isochrones in all three lakes are distinctly concavedownward in morphology (Fig. 7). There were certain divergences between the water levels in the nearby Lake Wigry through the same time period as the three smaller lakes of Wigry National Park (Kupryjanowicz et al. 2009), as compared to the model developed by 
Fig. 4 Lake Suchar II. Simplified pollen percentage diagram from (selected pollen curves only): a littoral zone,

b profundal zone
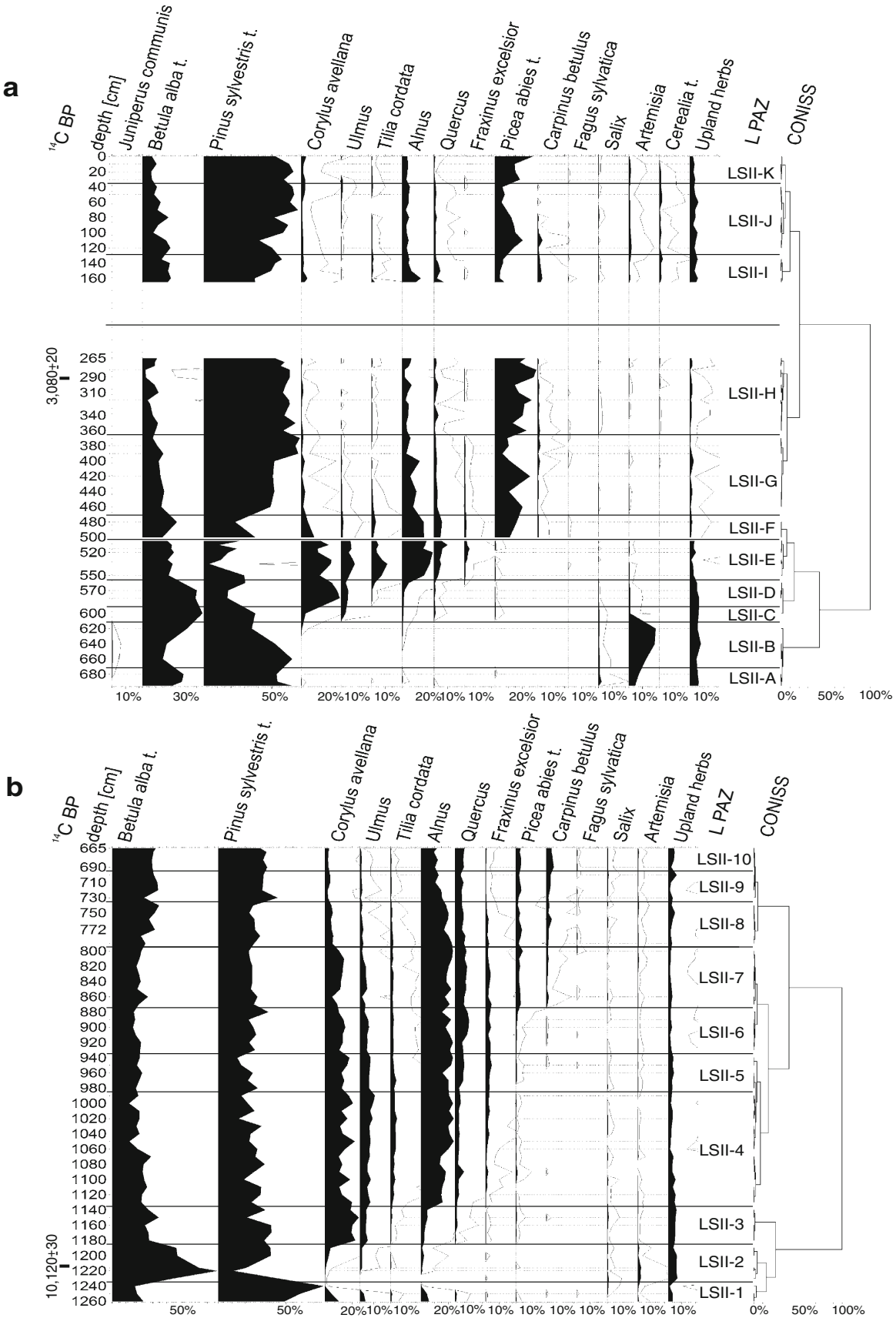

Ralska-Jasiewiczowa and Starkel (1988) for northern Poland (see Fig. 7, 8). Details follow below.

\section{Discussion}

Gaudig et al. (2006), who studied mires in Rügen and Brandenburg (Germany), were the first to attempt to use isochrones to understand the mechanism of peat accumulation. These authors characterized isochrone patterns in three kettle hole-shaped basins, defining isochrones as parallel or concave. In one of the studied mires (Herthamoor), Gaudig et al. (2006) observed concave isochrones, suggesting that the origin of this basin is not the most important control in isochrone development. Other significant factors are compaction 


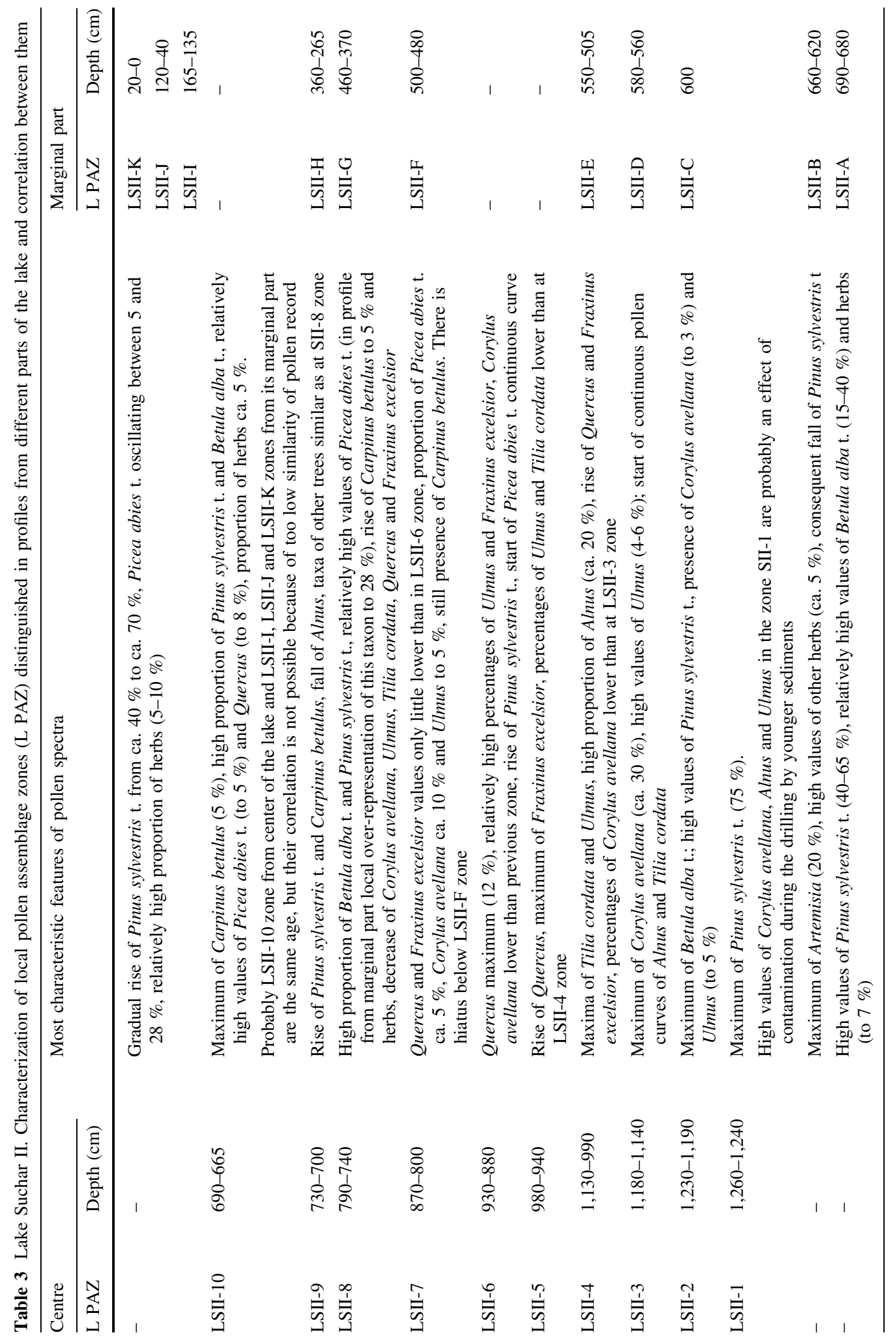


Fig. 5 Lake Suchar Wielki. Simplified pollen percentage diagram from (selected pollen curves only): a littoral zone,

b profundal zone
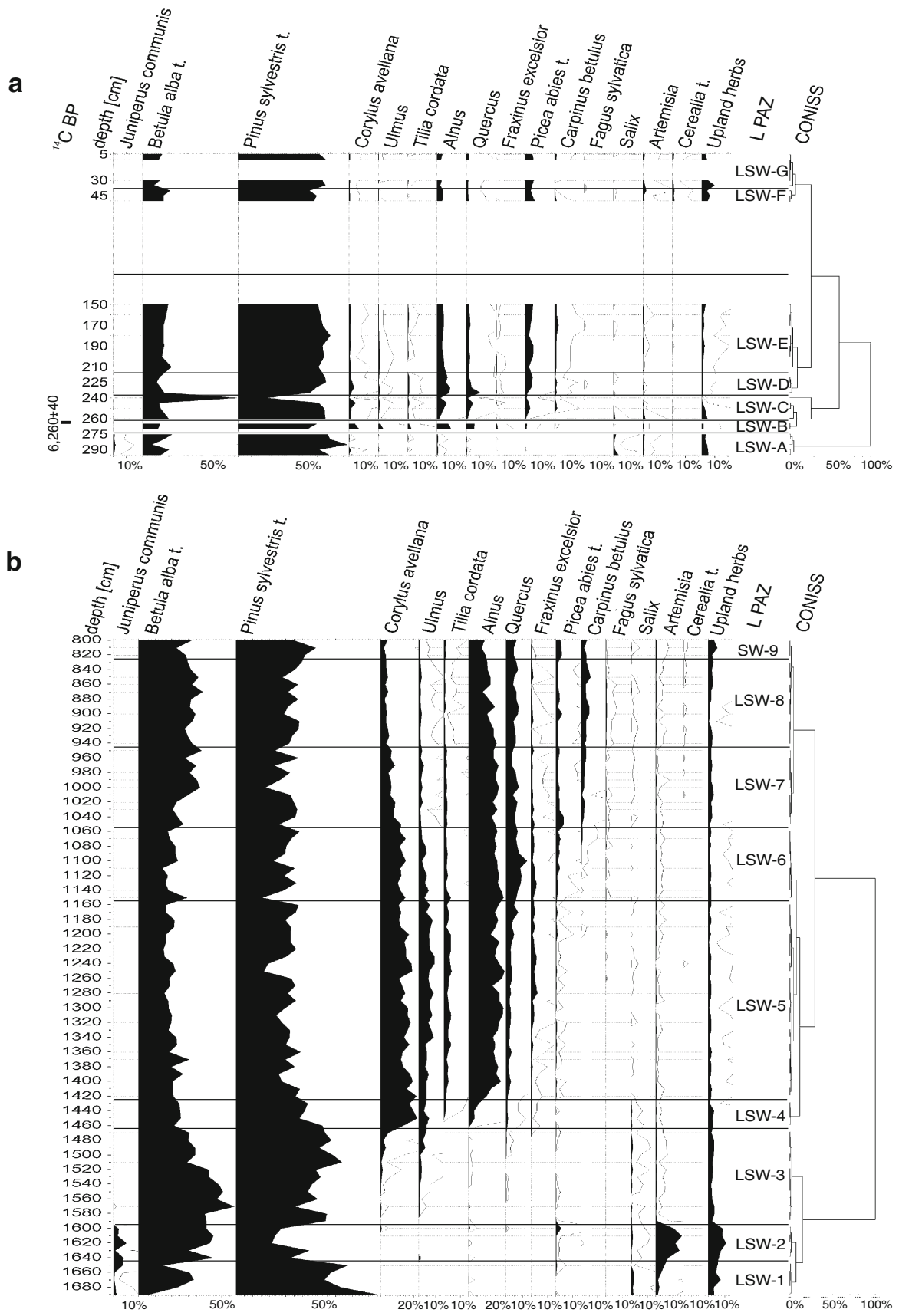

of sediments (Stegmann et al. 2001) and karst processes. In the landscape of northern Germany that is underlain by glacial sediment of various origins and even karstic limestone, this explanation is very probable. However, such interpretation of isochrone pattern cannot be universally applied since the shape of a lake basin for a kettle hole is not unique and the subsurface sediment patterns change with every area.
Also, isochrones patterns seem to be controlled by hydrology, i.e. connection to regional groundwater levels.

In our study, the question of whether the studied lakes are kettle holes might only be applicable to the early phases of their development, when the marginal floating mats were not yet present. These phases include all of the isochrones in L. Ślepe (LS-1/LS-A, 
Table 4 Lake Suchar Wielki. Characterization of local pollen assemblage zones (L PAZ) distinguished in profiles from different parts of the lake and correlation between them

\begin{tabular}{|c|c|c|c|c|}
\hline \multicolumn{2}{|l|}{ Centre } & \multirow[t]{2}{*}{ Most characteristic features of pollen spectra } & \multicolumn{2}{|c|}{ Marginal part } \\
\hline L PAZ & Depth $(\mathrm{cm})$ & & L PAZ & Depth $(\mathrm{cm})$ \\
\hline LSW-9 & $820-800$ & $\begin{array}{l}\text { Increase of Pinus sylvestris t., Picea abies t. and herbs, fall of Betula alba } \\
\text { t. and Carpinus betulus }\end{array}$ & LSW-G & $35-5$ \\
\hline LSW-8 & $940-830$ & $\begin{array}{l}\text { Culmination of Carpinus betulus, light increase of Quercus, still presence } \\
\text { of Picea abies t., low percentage of Corylus avellana, fall of Alnus }\end{array}$ & LSW-F & $50-40$ \\
\hline \multirow[t]{3}{*}{ LSW-7 } & \multirow[t]{3}{*}{$1,050-950$} & \multirow{3}{*}{$\begin{array}{l}\text { Fall of Quercus, Ulmus, Tilia cordata and Corylus avellana, peak of } \\
\text { Picea abies t., increase of Carpinus betulus and Betula alba } \mathrm{t}\end{array}$} & LSW-E & $210-150$ \\
\hline & & & LSW-D & $235-220$ \\
\hline & & & LSW-C & $260-240$ \\
\hline \multirow[t]{2}{*}{ LSW-6 } & $1,150-1,060$ & $\begin{array}{l}\text { Maximum of Quercus, high proportion of Alnus and Corylus avellana, } \\
\text { fall of Ulmus and Tilia cordata, rise of Picea abies t. and Carpinus } \\
\text { betulus }\end{array}$ & LSW-B & $270-265$ \\
\hline & & There are hiatuses below and above of LSW-B zone & & \\
\hline LSW-5 & $1,420-1,160$ & $\begin{array}{l}\text { High values of Alnus and Corylus avellana, maxima of Ulmus, Tilia } \\
\text { cordata and Fraxinus excelsior, increase of Quercus }\end{array}$ & - & - \\
\hline LSW-4 & $1,460-1,430$ & $\begin{array}{l}\text { Maximum of Corylus avellana (20\%), increase of Alnus, fall of Pinus } \\
\text { sylvestris t }\end{array}$ & - & - \\
\hline LSW-3 & $1,590-1,470$ & $\begin{array}{l}\text { Very high proportion of Pinus sylvestris t., maximum of Betula alba t., } \\
\text { rising pollen curves of Corylus avellana and Ulmus }\end{array}$ & - & - \\
\hline LSW-2 & $1,640-1,600$ & $\begin{array}{l}\text { Maxima of Juniperus communis }(10 \%) \text {, Artemisia }(15 \%) \text { and other } \\
\text { herbs }(10 \%) \text {, depression of Pinus sylvestris } \mathrm{t} \text {, increase of Betula alba } \mathrm{t}\end{array}$ & - & - \\
\hline LSW-1 & $1,690-1,650$ & $\begin{array}{l}\text { High values of Pinus sylvestris t. with maximum of } 80 \% \text {, curve of Betula } \\
\text { alba t. rising to } 30 \% \text {, relatively high proportion of herbs }(10-15 \%) \\
\text { and Salix }(1-5 \%) \text {, still presence of Juniperus communis }\end{array}$ & LSW-A & $295-275$ \\
\hline
\end{tabular}

LS-B; LS-2/LS-C; LS-3/LS-D), the oldest four in L. Suchar II (LSII-1, LSII-2/LSII-C; LSII-3/LSII-D; LSII-4/LSII-E; LSII-7/LSII-F), and the oldest one in L. Suchar Wielki (LSW-1/LSW-A) (Fig. 7). All these isochrones are distinctly concave (Fig. 7). Thus, selfsealing processes seem to be not present in the lakes studied, indicating that these water bodies are not kettle holes disconnected from the regional groundwater table.

The top layers in the marginal cores from each of the three lakes consisted of Sphagnum peat, which was associated with the floating mats observed in each lake. Consequently, the formation of isochrones was dependent on the lateral expansion of the floating mats; this association matches certain features of the German Herthamoor deposit, studied by Gaudig et al. (2006).

Isochrones versus water levels

The presence of standing water through time (i.e. water levels) as related to regional groundwater levels is a major control of peat as well as coal development
(Bohacs and Suter 1997). The maintenance of water levels for peat development characterized by regional or localized groundwater levels can be inferred from the preservation or destruction of peat layers through time. Isochrone patters are dependent upon whether the water levels of the lake or mire are connected to the regional groundwater aquifer or not.

\section{Lake Ślepe}

The oldest isochrone identified in L. Ślepe represents the Preboreal period (LS-1/LS-A, LS-B; Fig. 7), which is confirmed by both the pollen record and radiocarbon dating (11,042-10,796 cal BP) of a peat sample from the marginal core (Fig. 3; Table 1). Correlation between the beginning of sediment accumulation in the central lake basin and in the littoral zone in the early Holocene indicates that water level in the lake was sufficiently high to reach the marginal zone and allow peat accumulation.

High water levels are also noted in the Boreal and Atlantic periods, as confirmed by the delineation of the 


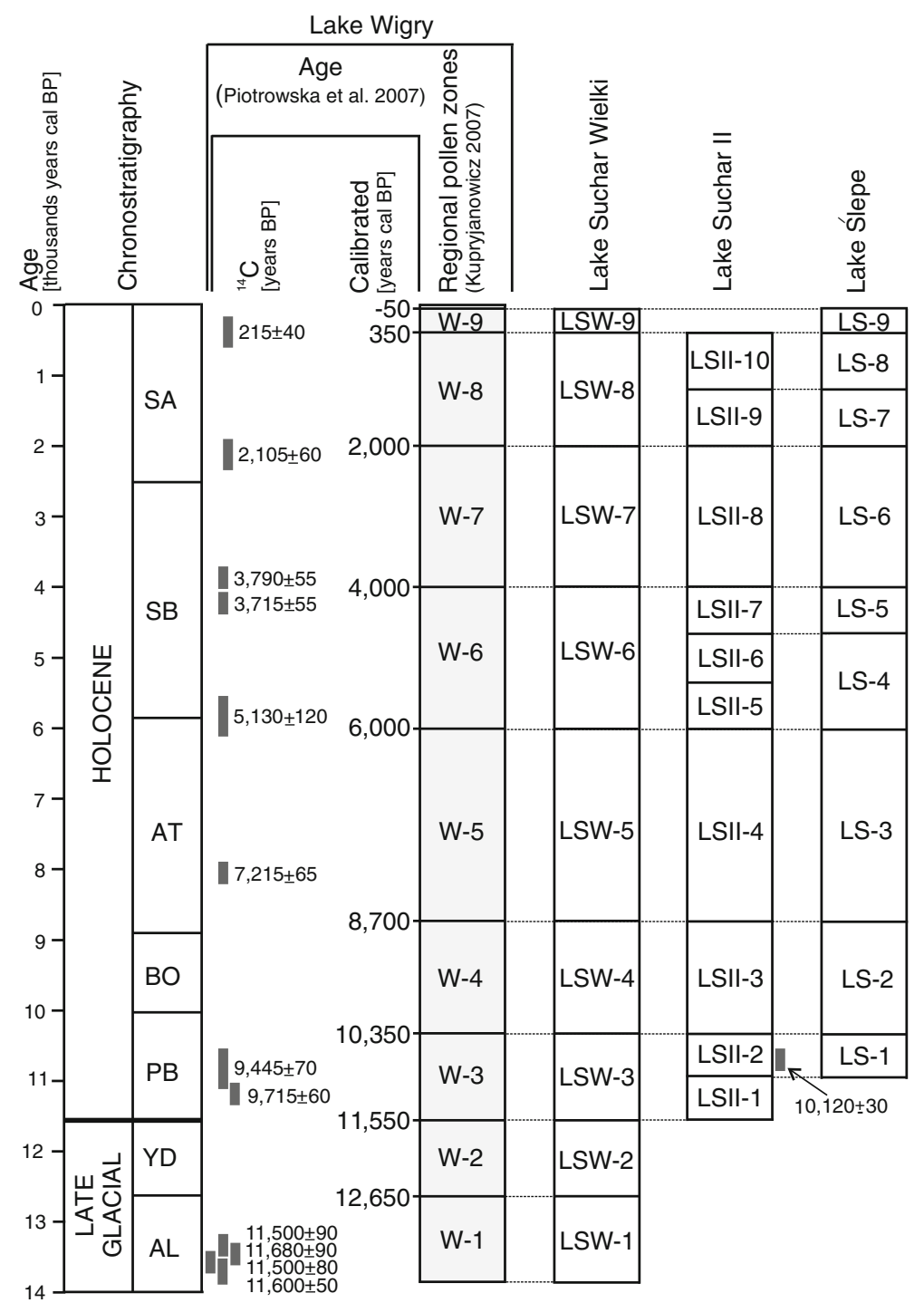

Fig. 6 Chronostratigraphical correlation of lake cores with radiometrically well-dated profile from Lake Wigry. Chronostratigraphy of Late Glacial according to Litt et. al. (2001) and Holocene according to Mangerud et al. (1974), with calibration

LS-2/LS-C and LS-3/LS-D isochrones, respectively (Fig. 7). This differentiates L. Ślepe from Lake Wigry and some other lakes in northern Poland, where falling water levels are noted from the Boreal period (RalskaJasiewiczowa and Starkel 1988; Kupryjanowicz et al. 2009; Drzymulska and Zieliński 2013) as a result of the warm climate, with a high rate of evaporation, which limited the results of high precipitation (RalskaJasiewiczowa and Starkel 1988). These falling water levels were not most likely very marked at L. Ślepe of boundaries by Walanus and Nalepka (2010). AL Allerod, $Y D$ Younger Dryas, $P B$ Preboreal, $B O$ Boreal, $A T$ Atlantic, $S B$ Subboreal, $S A$ SubAtlantic. Ages shown are from Piotrowska et al. (2007)

because, by this time, the lake was already surrounded by dense forest, indicated by the pollen record, which perhaps reduced evaporation rates.

Neither Subboreal nor Subatlantic isochrones are present; there are no Subboreal and lower Subatlantic sediments in the marginal zone, and there are no upper Subatlantic sediments in the center of the lake (Fig. 7). Conditions for the preservation of these isochrones may have been impossible perhaps because of changes in drainage and degradation of these peat layers before 


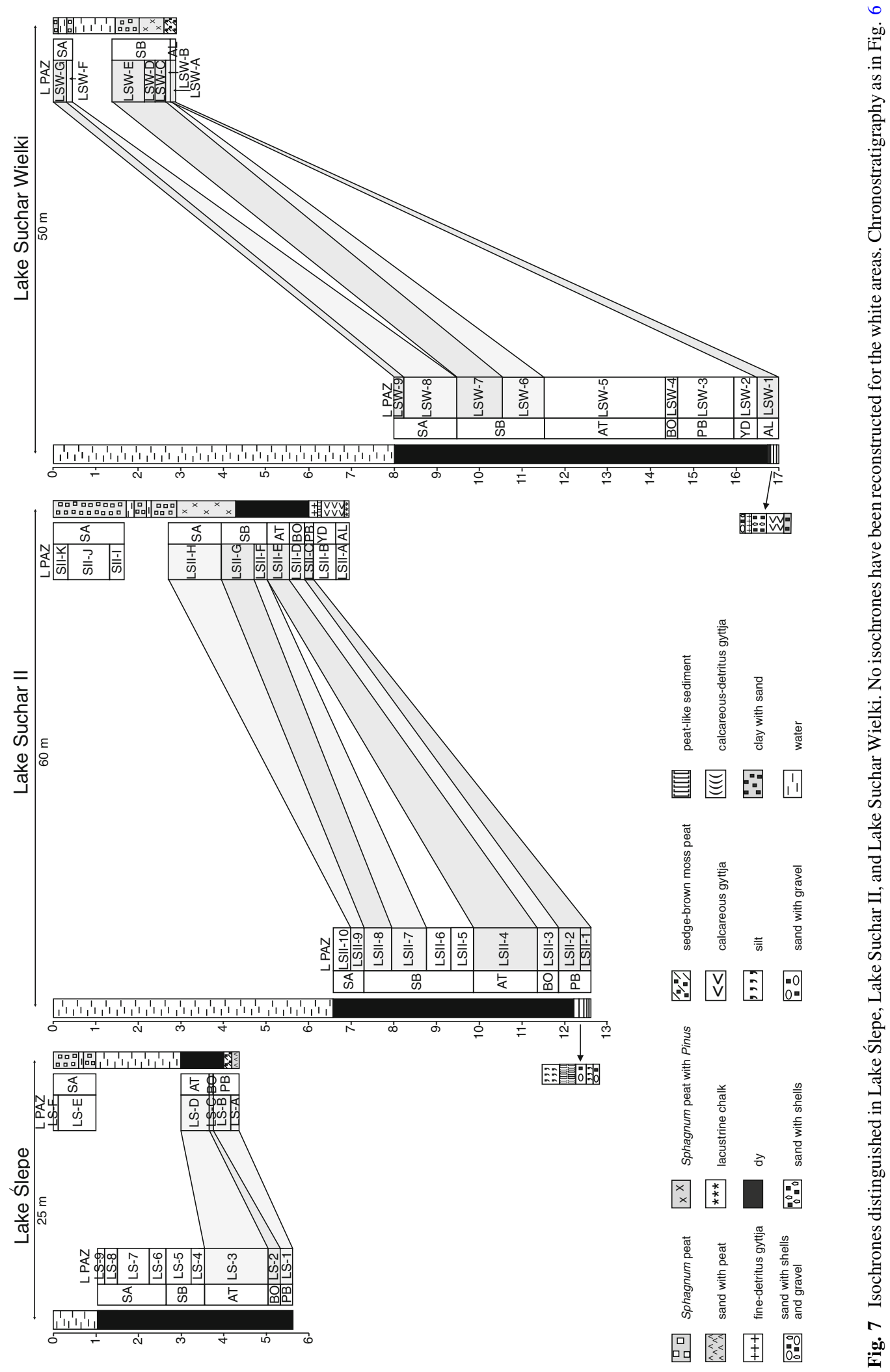


burial. The differences in the pollen record between the marginal and profundal cores, which rendered pollen zone correlation impossible, may have stemmed from the fact that the sediments from the profundal zone preserved the regional pollen record, whereas the record from the littoral zone contained pollen of the plants growing nearby the lake, mainly (Latałowa 2003).

\section{Lake Suchar II}

The oldest sedimentary layers formed during the Allerød and Younger Dryas are only identified in the littoral zone of L. Suchar II (LSII-A and LSII-B; Fig. 4). There are calcareous sediments (lacustrine chalk and calcareous gyttja) containing the remains of charophytes, above which there is detritus-calcareous gyttja. It is likely that dead ice was present in the basin throughout the Late Glacial period. The central part of the dead ice melted from the beginning of the Allerød until the Preboreal period. The long time for the melting of the dead ice is indicated by the presence of peat-like sediment in the profundal core. Only after the dead ice melted could peat-like material be deposited on the lake bottom (see Błaszkiewicz 2007). The presence of dead ice on the North European Plain until the Preboreal period is confirmed by data from numerous locations (Böse 1995; Błaszkiewicz 2002). Lacustrine sedimentation could only occur in the marginal parts of this small water body as a consequence of this ice melting. The presence of charophytes indicates that the depth of this lake basin may have ranged from only tens of $\mathrm{cm}$ to more than $10 \mathrm{~m}$ (Hannon and Gaillard 1997). However, charophytes are usually present in water no deeper than $10 \mathrm{~m}$ (Pełechaty et al. 2010).

From the Preboreal period, L. Suchar II occupied the entire lake depression, as indicated by the isochrone representing this period (LSII-1, LSII-2/LSII-C; Fig. 7). This isochrone's age was confirmed by radiocarbon dates from the profundal core $(11,975-11,505$ cal BP; Figs. 4 and 6; Table 1). It is clear that the water levels in the lake at that time were sufficiently high for the accumulation of lacustrine organic sediments (finedetritus gyttja and dy) in the marginal zone.

The high water level in the vicinity of L. Suchar II was maintained during the Boreal and Atlantic periods, as in the L. Ślepe (see above). The evidence for the high level in L. Suchar II is the presence of lacustrine sediments in the littoral zone, which permitted development of isochrones LSII-3/LSII-D and LSII-4/LSII-E (Fig. 7).

A decline in precipitation during the Younger Atlantic and Subboreal periods caused a drop in the lake water level and an end to peat accumulation in the marginal areas. The same tendency was noted in other lakes in northern Poland (Ralska-Jasiewiczowa and Starkel 1988; Kupryjanowicz et al. 2009) and central Poland (Pazdur et al. 1995), as well as in central Europe (e.g., the Jura Mountains, the northern French Alps, and the Swiss Plateau (Magny and Ruffaldi 1995; Magny et al. 2001; Magny 2004) and northern Europe [e.g., Finland (Ikonen 1993) and Estonia (Punning et al. 2003)]. In the case of L. Suchar II, which has a very small catchment and catchment: lake ratio ( 9.7 ha and 3.73 , respectively), this drop in water level may have been especially pronounced. Such a pronounced drop may explain the lack of an isochrone dating to the older part of the Subboreal period and can be attributed to regional climatic conditions. Conversely, the hydrological conditions in L. Suchar II changed during the younger part of the Subboreal period. The presence of isochrones LSII-7/LSII-F, and LSII-8/LSII-G indicated that the water level was high both in the central lake area and along its margin.

Such hydrological changes not in synchrony with documented regional climate changes have to be attributed to local factors (Harrison et al. 1993), such as drainage changes and its affects on the subsurface geology and resultant groundwater flow patterns. The L. Suchar II margin transformed into a bog, where Sphagnum peat with Pinus accumulated, followed by Sphagnum peat (3,365-3,245 cal BP; Fig. 4; Table 1). An isochrone corresponding to the younger part of the Subatlantic period may be lacking for the same reasons that one is lacking from the top of the core from L. Ślepe.

\section{Lake Suchar Wielki}

The oldest isochrone of all those delimited in the present study was derived from L. Suchar Wielki. This isochrone was dated to the Allerød (LSW-1/LSW-A; Fig. 7) - the main period of lake formation in young glacial areas (Żurek 1995; Starkel et al. 1996; Kaiser 2004; Błaszkiewicz 2007). The primary time of dead ice melting occurred during the Allerød, when most of the warming during the Late Glacial period occurred. This explains the development of numerous mires, as well as shallow, vegetated water bodies 

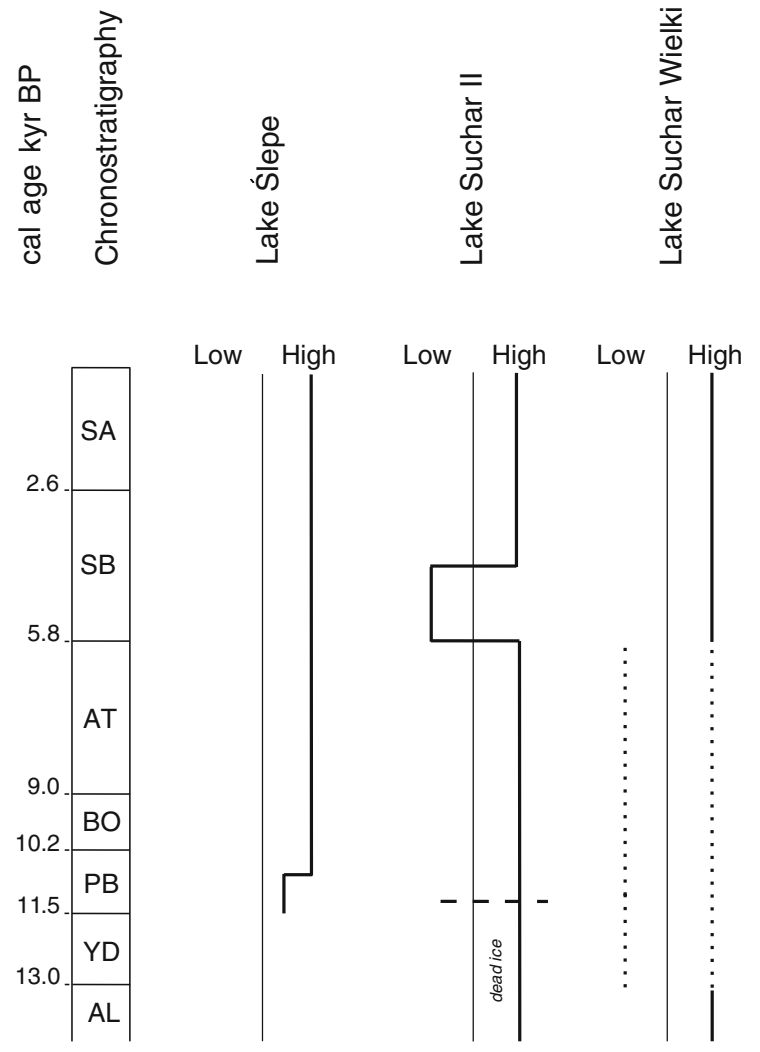

Fig. 8 Changes of water level in the three studied lakes. Dotted lines correspond to two possible water levels in L. Suchar Wielki in the phase from Younger Dryas to Subboreal (explanations in the text). A dashed line shows the probable time limits associated with the presence of dead ice in L. Suchar II. Chronostratigraphy as in Fig. 6

(Alexandrowicz 2009) and other dystrophic lakes (Drzymulska et al. 2013) in the vicinity of Lake Wigry. L. Suchar Wielki was a result of the early melting of dead ice, as indicated by the presence of calcareous and fine-detritus gyttja at the bottom of the studied profundal core. Brown moss communities that formed sedge-brown moss peat were present in the bottom section of the littoral zone core; this type of plant community indicated high groundwater levels (Kloss 2005).

Lake level dropped at the beginning of the Younger Dryas stadial, interrupting the accumulation of peat on the shores of L. Suchar Wielki. These conditions persisted through the Preboreal, Boreal, and Atlantic periods with the marginal core lacking pollen zones that correspond to these periods (pollen zones from LSW-2 to LSW-5; Fig. 7). Similar gaps in sediment accumulation are present in many of the profiles and are known as hiatuses (Rybníček and Rybníčková 1987; Digerfeldt et al. 2007). These hiatuses result from the shrinking of sedimentation limits associated with decreasing lake level (Magny 2001).

Another possible explanation for this lack of preserved isochrones for the Preboreal through Atlantic periods may be intensive sliding and slumping processes (see Dearing 1997). Evidence for mixing of the sediment in these zones can be found in the age determinations. Radiocarbon dating (7,243-7,165 cal BP; Fig. 5; Table 1) indicated that the bottom sample of the Subboreal sediments, which lie directly over the Allerød sediments, was older than was anticipated based on the pollen record. There are hiatuses in this part of the core as well. These findings suggest that younger and older sediments may be mixed and inverted in this layer. High precipitation, as noted in the younger half of the Boreal period in northern Poland (Ralska-Jasiewiczowa and Starkel 1988), may have been a factor that induced this sediment mixing.

The cessation of these processes took place in the Subboreal period as a result of natural shallowing of the lake and perhaps decreasing precipitation (RalskaJasiewiczowa and Starkel 1988). Two isochrones from the Subboreal period were identified (LSW-6/LSW-B and LSW-7/LSW-C, LSW-D, LSW-E) (Fig. 7). As in L. Suchar II, the littoral zone of L. Suchar Wielki was transformed into a bog. Sphagnum peat with Pinus and Sphagnum peat accumulated, and precipitation was most likely heavy in the younger part of the Subboreal period, which was conducive to the formation of a thick layer of peat (LSW-E L PAZ).

In the profundal zone of L. Suchar Wielki, two Subatlantic isochrones were identified (LSW-8/LSWF and LSW-9/LSW-G) (Fig. 7). The water level was high in the lake, and accumulation was therefore undisturbed throughout the lake basin.

\section{Conclusions}

As documented by the concave shape of the isochrones, peat development in the studied Wigry park dystrophic lakes was controlled by the high regional groundwater levels linked to wetter climates with drier climates linked to non-deposition in most cases. High water levels throughout the Holocene was noted only in L. Ślepe while other lakes in the region experienced a fall in water levels during the Boreal period. Lower water 
tables were identified in the older part of the Subboreal period in L. Suchar II, whereas in L. Suchar Wielki, this decrease persisted over a longer period, from the Younger Dryas to the Subboreal period (Fig. 8). There were clearly some different trends in water level fluctuations in the Wigry park lakes in comparison to those in other lakes in the region. Thus, changes in water levels cannot be assumed to have been only climatically driven, otherwise they would have been regionally synchronous (Harrison and Digerfeldt 1993). It must be assumed that changes in lake levels were also driven by localized non-climatic factors (Magny 2001), such as the size of catchment, catchment/lake ratio, shape of the lake basins (high slopes), groundwater hydrology, and development of local stream networks.

Delineating isochrones is a good approach to analyzing the accumulation of sediments through time, which simplifies reconstruction of the past hydrological conditions of lakes and mires. However, to understand the regional groundwater patterns through time, the past climate and the characterization of the subsurface geology is critical.

Acknowledgments We are very grateful to Professor Adam Walanus for consultation regarding statistical methods used in our studies. We thank Professor Mirosław Błaszkiewicz for useful suggestions concerning the postglacial development of lakes. We also would like to thank the anonymous reviewers for their comprehensive reading of the manuscript and constructive suggestions for its improvement. The research was financed by the Ministry of Science and Higher Education in Poland, project nr NN305085135 "History of dystrophic lakes of the Wigry National Park in the light of the Holocene succession of their vegetation" (Principal Investigator: Danuta Drzymulska). Magdalena Fiłoc was also supported by the Podlasie Province Marshal's Office, Poland, and by WOTT University of Bialystok for the scholarship designated for the project "Podlasie Scholarship Fund", Priority of VIII Operation Program Human Capital, financed by the European Social Fund (ESF) and the Polish government.

Open Access This article is distributed under the terms of the Creative Commons Attribution License which permits any use, distribution, and reproduction in any medium, provided the original author(s) and the source are credited.

\section{References}

Alexandrowicz WP (2009) Zmiany środowiska naturalnego w jeziorze Wigry w czasie późnego glacjału i holocenu w świetle badań mięczaków. In: Rutkowski J, Krzysztofiak L (eds) Jezioro Wigry. Historia jeziora w świetle badań geologicznych i paleoekologicznych, Stowarzyszenie Człowiek i Przyroda, Suwałki, pp 227-240

Ber A (2009) Budowa geologiczna, geomorfologia i geneza obrzeżenia jeziora Wigry w nawiązaniu do struktur głębokiego podłoża. In: Rutkowski J, Krzysztofiak L (eds) Jezioro Wigry. Historia jeziora w świetle badań geologicznych i paleoekologicznych, Stowarzyszenie Człowiek i Przyroda, Suwałki, pp 13-30

Berglund BE, Ralska-Jasiewiczowa M (1986) Pollen analysis and pollen diagrams. In: Berglund BE (ed) Handbook of Holocene palaeoecology and palaeohydrology. Wiley, Chichester, pp 455-484

Beug HJ (2004) Leitfaden der Pollenbestimmung fur Mitteleuropa und angrenzende Gebiete. Publisher Verlag Friedrich Pfeil, Munich

Björk S (2010) The evolution of lakes and wetlands. In: Eiseltová M (ed) Restoration of lakes, streams, floodplains, and bogs in Europe: principles and case studies. Springer, Dordrecht, pp 25-35

Błaszkiewicz M (2002) Spätglaziale und frühholozäne seebeckenentwicklung im östlichen Teil von Pommern (Polen). Greifswald Geogr Arb 26:11-14

Błaszkiewicz M (2007) Geneza i ewolucja mis jeziornych na mlodoglacjalnym obszarze Polski-wybrane problemy. Stud Lim et Tel 1:5-16

Bloesch J (2004) Sedimentation and lake sediment formation. In: O'Sullivan PE, Reynolds CS (eds) The lakes handbook. Limnology and limnetic ecology. Blackwell Publishing, Oxford, pp 197-229

Bohacs K, Suter J (1997) Sequence stratigraphic distribution of coaly rocks: fundamental controls and paralic examples. Am Assoc Pet Geol B 81:1612-1639

Böse M (1995) Problems of dead ice and ground ice in the central part of the North European Plain. Quat Int 28:123-125

Bronk Ramsey C (2009) Bayesian analysis of radiocarbon dates. Radiocarbon 51:337-360

Dearing JA (1997) Sedimentary indicators of lake-level changes in the humid temperate zone: a critical review. J Paleolimnol 18:1-14

Digerfeldt G (1986) Studies on past lake-level fluctuations. In: Berglund BE (ed) Handbook of Holocene palaeoecology and palaeohydrology. Wiley, Chichester, pp 127-143

Digerfeldt G, Sandgren P, Olsson S (2007) Reconstruction of Holocene lake-level changes in Lake Xinias, central Greece. Holocene 17:361-367

Drzymulska D, Zieliński P (2013) Developmental changes in the historical and present-day trophic status of brown water lakes. Are humic water bodies a uniform aquatic ecosystem? Wetlands 33:909-919

Drzymulska D, Kłosowski S, Pawlikowski P, Zieliński P, Jabłońska E (2013) The historical development of vegetation of foreshore mires beside humic lakes: different successional pathways under various environmental conditions. Hydrobiologia 703:15-31

Filion L, Bégin Y (1998) Recent paludification of kettle holes on the central islands of Lake Bienville, northern Québec, Canada. Holocene 8:91-96

Gaudig G, Couwenberg J, Joosten H (2006) Peat accumulation in kettle holes: bottom up or to down? Mires Peat 1:1-16 
Grimm EC (1987) CONISS: a FORTRAN 77 program for stratigraphically constrained cluster analysis by the method of incremental sum of squares. Comput Geosci 13:13-35

Hannon GE, Gaillard MJ (1997) The plant-macrofossil record of past lake-level changes. J Paleolimnol 18:15-28

Harrison SP, Digerfeldt G (1993) European lakes as palaeohydrological and palaeoclimatic indicators. Quat Sci Rev 12:233-248

Harrison SP, Prentice C, Guiot J (1993) Climatic controls on Holocene lake-level changes in Europe. Clim Dynam 8:189-200

Ikonen L (1993) Holocene development and peat growth of the raised bog Pesänsuo in southwestern Finland. Geol Surv Finl 370:1-79

Joosten H, Succow M (2001) Hydrogenetische Moortypen. In: Succow M, Joosten H (eds) Landschaftsökologische Moorkunde. Schweizerbart, Stuttgart, pp 234-240

Kaiser K (2004) Lake basin development in the Endinger Bruch area (Vorpommern, NE Germany) during the Late Pleistocene and Early Holocene. Z Geomorphol 48:461-480

Kalettka T, Rudat C (2006) Hydrogeomorphic types of glacially created kettle holes in North-East Germany. Limnologica 26:54-64

Kloss M (2005) Identification of subfossil plant communities and palaeohydrological changes in raised mire development. Monogr Bot 94:81-116

Kondracki J (1994) Geografia Polski. Mezoregiony fizycznogeograficzne, PWN, Warszawa

Kowalewski G, Milecka K (2003) Palaeoecology of basins of organic sediment accumulation in the Reserve Dury. Stud Quat 20:73-82

Kupryjanowicz M (2007) Postglacial development of vegetation in the vicinity of the Wigry Lake. Geochronometria 27:53-66

Kupryjanowicz M, Piotrowska N, Rutkowski J, Krzysztofiak L (2009) Podsumowanie. In: Rutkowski J, Krzysztofiak L (eds) Jezioro Wigry. Historia jeziora w świetle badań geologicznych i paleoekologicznych, Stowarzyszenie Człowiek i Przyroda, Suwałki, pp 256-264

Lamentowicz M, Tobolski K, Mitchell AD (2007) Palaeoecological evidence for anthropogenic acidification of a kettlehole peatland in northern Poland. Holocene 17:1185-1196

Latałowa M (2003) Późny Vistulian. In: Dybova-Jachowicz S, Sadowska A (eds) Palinologia. Wydawnictwa Instytutu Botaniki PAN, Kraków, pp 266-273

Litt T, Brauer A, Goslar T, Merkt J, Bałaga K, Müller H, Ralska-Jasiewiczowa M, Stebich M, Negendank JFW (2001) Cerrelation and synchronisation of Lateglacial continental sequences in northern central Europe based on annually laminated lacustrine sediments. Quat Sci Rev 20:1233-1249

Magny M (2001) Palaeohydrological changes as reflected by lake-level fluctuations in the Swiss Plateau, the Jura Mountains and the northern French Pre-Alps during the Last Glacial-Holocene transition: a regional synthesis. Global Planet Change 30:85-101

Magny M (2004) Holocene climate variability as reflected by mid-European lake-level fluctuations and its probable impact on prehistoric human settlements. Quat Int 113:65-79
Magny M, Ruffaldi P (1995) Younger Dryas and early Holocene lake-level fluctuations in the Jura mountains, France. Boreas 24:155-172

Magny M, Marguet A, Chassepot G, Richard H, Billaud Y (2001) Early and late Holocene water-level fluctuations of Lake Annecy, France: sediment and pollen evidence and climatic implications. J Paleolimnol 25:215-227

Mangerud J, Andersen ST, Berglund BE, Donner JJ (1974) Quaternary stratigraphy of Norden, a proposal for terminology and classification. Boreas 3:109-128

Marks L (2002) Last Glaciation maximum in Poland. Quat Sci Rev 21:103-110

Nalepka D, Walanus A (2003) Data processing in pollen analysis. Acta Palaeobot 43:125-134

Pazdur A, Fontugne MR, Goslar T, Pazdur MF (1995) Lateglacial and Holocene water-level changes of the Gościąż Lake, Central Poland, derived from carbon isotopes studies of laminated sediments. Quat Sci Rev 14:125-135

Pełechaty M, Apolinarska K, Pukacz A, Krupska J, Siepak M, Boszke P, Sinkowski M (2010) Stable isotope composition of Chara rudis incrustation in Lake Jasne, Poland. Hydrobiologia 656:29-42

Piotrowska N, Hajdas I, Bonani G (2007) Construction of the calendar timescale for Lake Wigry (NE Poland) sediments on the basis of radiocarbon dating. Radiocarbon 49:1133-1143

Punning J, Kangur MM, Koff T, Possnert G (2003) Holocene lake-level changes and their reflection in the paleolimnological records of two lakes in northern Estonia. J Paleolimnol 29:167-178

Ralska-Jasiewiczowa M, Starkel L (1988) Record of the hydrological changes during the Holocene in the lake, mire and fluvial deposits of Poland. Folia Quat 57:91-126

Ralska-Jasiewiczowa M, Latałowa M, Wasylikowa K, Tobolski K, Madeyska E, Wright HE Jr, Turner CH (2004) Late Glacial and Holocene history of vegetation in Poland based on isopollen maps W. Szafer Institute of Botany. Polish Academy of Sciences, Kraków

Rybníček K, Rybníčková E (1987) Palaeogeobotanical evidence of the middle Holocene stratigraphic hiatuses in Czechoslovakia and their explanation. Folia Geobot Phytotax 22:313-327

Schindler U (1996) Untersuchungen zum Wasserhaushalt kleiner Binneneinzugsgebiete mit Söllen im Nordostdeutschen Jungmoränengebiet. Naturschutz und Landschaftspflege in Brandenbur. Sonderheft 1996:39-43

Schnurrenberger D, Russell J, Kelts K (2003) Classification of lacustrine sediments based on sedimentary components. J Paleolimnol 29:141-154

Starkel L, Pazdur A, Pazdur MF, Wicik B, Więckowski K (1996) Lake-level and groundwater-level changes in the lake Gościąż area. Poland: palaeoclimatic implications. Holocene 6:213-224

Stegmann H, Edom F, Koska I (2001) Bodenbildende Prozesse waschender Moore. In: Succow M, Joosten H (eds) Landschaftsökologische Moorkunde. Schweizerbart, Stuttgart, pp 42-47

Stewart RE, Kantrud HA (1971) Classification of natural ponds and lakes in the glaciated prairie region. Bureau of Sport Fisheries and Wildlife, U.S. Fish and Wildlife Service, Washington 
Timmermann T (2000) Oscillation or inundation: hydrodynamical classification of kettle-hole mires as a tool for restoration. In: Rochefort L, Daigle J-Y (eds), Sustaining our Peatlands. Proceedings of the eleventh international peat congress, Volume 1. International peat society, Quebec, pp 243-252

Timmermann T, Succow M (2001) Kesselmoore. In: Succow M, Joosten $\mathrm{H}$ (eds) Landschaftsökologische Moorkunde. Schweizerbart, Stuttgart, pp 379-390

Tobolski K (2000) Vademecum Geobotanicum. Przewodnik do oznaczania torfów i osadów jeziornych, Wydawnictwo Naukowe PWN, Warszawa

Walanus A (1995) Komputerowa baza danych zliczeń ziarn pyłku. Wiad Bot 39:41-46
Walanus A, Nalepka D (1999) POLPAL. Program for counting pollen grains, diagrams plotting and numerical analysis. Acta Palaeobot Suppl 2:659-661

Walanus A, Nalepka D (2006) Numerical correlation of many multidimensional geological records. Ann Soc Geol Pol 76:215-224

Walanus A, Nalepka D (2010) Calibration of Mangerud's boundaries. Radiocarbon 52:1639-1644

Żurek S (1995) The development of the peat forming process versus the lowland relief of Poland and hydrological changes in the Postglacial period. Quaest Geogr 17(18):95-100

Żurek S, Bińka K, Szańkowski M, Kłosowski S (2006) Overgowing of lakes exemplified by Gajlik and Malona Mires (Sejny Lake District). Limnol Rev 6:295-304 